\title{
ANALIZA FORMULE ZA IZRAČUNAVANJE NIVOA RIZIKA
}

\author{
Mališa Žižovićn ${ }^{\star}$, Nada Damljanović \\ ${ }^{1}$ Univerzitet Singidunum, Poslovni fakultet u Valjevu, Železnička 5, Valjevo, Srbija \\ ${ }^{2}$ Univerzitet u Kragujevcu, Fakultet tehničkih nauka u Čačku, Svetog Save 65, Čačak, Srbija
}

\begin{abstract}
Apstrakt:
U ovom radu se osvrćemo na formulu prema kojoj se računa nivo rizika po Kinijevoj metodi: rizik se posmatra kao kvantitativna vrednost koja se dobija na osnovu verovatnoće realizacije nepovoljnog događaja, ozbiljnosti njegovih posledica (povrede, oboljenja, smrti) i učestalosti pojavljivanja te moguće opasnosti i štetnosti.
\end{abstract}

\section{UVOD}

Svaki poslodavac je u obavezi da proceni rizik sa aspekta bezbednosti i zdravlja njegovih zaposlenih. Ta procena, prvenstveno treba "da pomogne poslodavcima da prepoznaju opasnosti na radu" da bi se dalje, na osnovu nivoa procenjenog rizika, "odredile i primenile adekvatne mere za zaštitu zdravlja i bezbednost zaposlenih" (Unija poslodavaca Srbije, 2015). Procenjene opasnosti pomažu poslodavcima u izboru najprikladnije opreme, odnosno opremljenosti radnog mesta, kao i same organizacije rada. Poslodavci su u obavezi da provere da li su mere bezbednosti i zaštite na radu odgovarajuće, da preduzmu neophodne radnje za njihovu primenu, odnosno da primenjuju preventivne mere, a u slučaju procene o prisustvu opasnosti i štetnosti poslodavci su u obavezi da preduzmu mere za njihovo otklanjanje. "Izbor mera poslodavac utvrđuje polazeći od procenjenog rizika, utvrđenog prioriteta poštujući principe prevencije, u skladu sa propisima o bezbednosti i zdravlju na radu, tehničkim propisima, standardima ili opšte priznatim merama" (GS PUT Nezavisnost, 2015).

"Po proceni Međunarodne organizacije rada 2,2 miliona ljudi godišnje umre zbog loših uslova na radnom mestu, odnosno svakih 15 sekundi umire jedan radnik. U toku 2008. godine, u Srbiji su zabeležene 42 smrtne, 37 teških sa smrtnim ishodom, 997 teških povreda, 32 kolektivne i 177 lakih povreda na radu" (videti Starčević et al., 2010).

"Zakonom o bezbednosti i zdravlju na radu uvedena je obaveza za poslodavce koja se odnosi na sprovođenje procene rizika za sva radna mesta u jednom preduzeću, a procedura procene rizika propisana je Pravilnikom o načinu i postupku procene rizika na radnom mestu i u radnoj okolini" (Unija poslodavaca Srbije, 2015).

Unija poslodavaca Srbije (www.poslodavci.org.rs) dala je detaljne smernice za procenu nivoa rizika koje su urađene prema Pravilniku za čiju izradu je korišćena metodologija data u radu Kinney \& Wiruth (1976). Ovde prikazujemo (citiramo) deo tih smernica.

Polazna razmatranja u ovom modelu su:

- ozbiljnost posledica koje zaposleni trpi kod pojave opasnosti i štetnosti

- verovatnoća pojave opasnosti i štetnosti i

- učestalost pojavljivanja opasnosti i štetnosti.

Nivo rizika se definiše kao umnožak moguće štete (posledice), verovatnoće i učestalosti:

$$
\mathrm{R}=\mathrm{P} \times \mathrm{V} \times \mathrm{U}
$$

$(\mathrm{R}$ - nivo rizika, $\mathrm{P}$ - posledica,

$\mathrm{V}$ - verovatnoća, $\mathrm{U}$ - učestalost)

Posledice (P) (moguća šteta) se rangiraju od 1, kao najmanje, do 10, koja se smatra katastrofalnom. Prikaz je dat u sledećoj tabeli:

P O S L E I C E

\begin{tabular}{cl}
\hline RANG & \multicolumn{1}{c}{ OPIS KRITERIJUMA } \\
\hline 1 & $\begin{array}{l}\text { MALE - bolest (povreda), zahteva prvu pomoć } \\
\text { i nikakav drugi tretman. }\end{array}$ \\
\hline 2 & $\begin{array}{l}\text { ZNATNE - medicinski tretman od strane } \\
\text { lekara. }\end{array}$ \\
\hline 3 & $\begin{array}{l}\text { OZBILJNE - invalidnost, ozbiljna pojedinačna } \\
\text { povreda sa hospitalizacijom i izgubljenim } \\
\text { danima. }\end{array}$ \\
\hline 6 & $\begin{array}{l}\text { VEOMA OZBILJNE - pojedinačne nesreće sa } \\
\text { smrtnim ishodom. }\end{array}$ \\
\hline 10 & $\begin{array}{l}\text { KATASTROFALNE - sa višestrukim smrtnim } \\
\text { ishodima. }\end{array}$ \\
\hline
\end{tabular}


Kriterijum verovatnoće $(\mathrm{V})$ se rangira počev od 0,1 - jedva verovatna, do 10 koja se smatra izvesnom, predvidivom. Prikaz je dat u sledećoj tabeli:

\begin{tabular}{cl}
\hline & \multicolumn{2}{c}{ V E R O V A T N O Ć A } \\
\hline RANG & \multicolumn{1}{c}{ OPIS KRITERIJUMA } \\
\hline 0,1 & JEDVA POJMLJIVO \\
\hline 0,2 & PRAKTIČNO NEVEROVATNO \\
\hline 0,5 & POSTOJI, ALI SAMO MALO VEROVATNO \\
\hline 1 & MALA VEROVATNOĆA, ali moguće u ograničenim slučajevima. \\
\hline 3 & MALO MOGUĆE \\
\hline 6 & SASVIM MOGUĆE \\
\hline 10 & OČEKIVANO, predvidivo.
\end{tabular}

Kriterijum učestalost (U) se rangira od - retko (godišnje) (1), do trajno/kontinuirano (10). Prikaz je dat u sledećoj tabeli:

\begin{tabular}{cl}
\hline \multicolumn{1}{c}{ U Č E S T A L O S T } \\
\hline RANG & \multicolumn{1}{c}{ OPIS KRITERIJUMA } \\
\hline 1 & Izlaže se retko - GODIŠNJE \\
\hline 2 & Izlaže se MESEČNO \\
\hline 3 & Izlaže se NEDELJNO \\
\hline 6 & Izlaže se DNEVNO \\
\hline 10 & Izlaže se trajno KONTINUIRANO \\
\hline
\end{tabular}

Nivo rizika (R) se rangira od prihvatljivog, neznatnog - nivo I do ekstremnog, umeren (već povećan) rizik - III, nedopusti$\operatorname{vog}$ - nivo V, koji iziskuje prekid radne aktivnosti i hitno preduzimanje mera. Rangiranje nivoa rizika prikazuje sledeća tabela:

\begin{tabular}{ccl}
\hline $\begin{array}{c}\text { UKUPNA } \\
\text { OCENA }\end{array}$ & $\begin{array}{c}\text { NIVO } \\
\text { RIZIKA }\end{array}$ & \\
\hline 0,1-20 & $\begin{array}{c}\text { Prihvatljiv } \\
\text { (neznatan) } \\
\text { I }\end{array}$ & Ne zahteva se nikakva akcija. \\
\hline 21-70 & $\begin{array}{c}\text { Mali } \\
\text { (dopustiv) } \\
\text { II }\end{array}$ & $\begin{array}{l}\text { Nema potrebe za dodatnim aktivnostima pri upravljanju operacijom. Može se razmotriti ekonomski } \\
\text { isplativije rešenje ili unapređenje bez dodatnih ulaganja. Potrebno je pratiti situaciju, kako bi posedo- } \\
\text { vali informacije o sprovođenju propisanih aktivnosti. }\end{array}$ \\
\hline $71-200$ & $\begin{array}{c}\text { Umeren } \\
\text { III }\end{array}$ & $\begin{array}{l}\text { Potrebno je uložiti napor kako bi se smanjio rizik, ali troškovi prevencije moraju biti pažljivo plani- } \\
\text { rani i ograničeni do izvesnog nivoa. Potrebno je definisati rok za sprovođenje unapređenja. Kod onih } \\
\text { događaja kod kojih mogu nastupiti izuzetno opasne posledice, potrebno je dodatno proveriti verovat- } \\
\text { noću nastanka takvog događaja kako bi se definisao potreban nivo aktivnosti na ublažavanju rizika. }\end{array}$ \\
\hline 201-400 & $\begin{array}{c}\text { Visok } \\
\text { (znatan) } \\
\text { IV }\end{array}$ & $\begin{array}{l}\text { Ne sme se započeti sa datom aktivnošću dok nivo rizika ne bude snižen. Mogu biti potrebna dodatna } \\
\text { sredstva kako bi se rizik smanjio. Ako se rizik odnosi na sve započete aktivnosti, potrebno je predu- } \\
\text { zeti hitne akcije na smanjenju nivoa rizika. }\end{array}$ \\
\hline preko 400 & $\begin{array}{c}\text { Ekstremni } \\
\text { (nedopustiv) } \\
\text { V }\end{array}$ & $\begin{array}{l}\text { Aktivnost ne sme biti započeta, ni nastavljena, sve dok se nivo rizika ne smanji. Ako ni ulaganjem } \\
\text { neograničenih sredstava nije moguć smanjiti nivo rizika, aktivnost mora ostati zabranjena. }\end{array}$ \\
\hline
\end{tabular}

Nizak nivo rizika ne zahteva primenu dodatnih mera zaštite, kod umerenog rizika, potrebno je razmotriti primenu mera za smanjenje rizika dok je kod visokog rizika neophodno sprovesti momentalne mere zaštite.

\section{REZULTATI I DISKUSIJA}

Sama formula nivoa rizika neke pojave $\mathrm{R}$

$$
\mathrm{R}=\mathrm{P} \times \mathrm{V} \times \mathrm{U}
$$

sadrži umnožak posledice pojave $\mathrm{P}$, procenjene verovatnoće $\mathrm{V}$ i učestalosti pojave $\mathrm{U}$. Sve tri veličine su dovedene na istu gornju meru 10 , dok je donja mera verovatnoće 0,1 a druge dve veličine je 1 .

Matematička definicija verovatnoće istu smešta u interval $[0,1]$, dakle ako ovo uzmemo u obzir i dovedemo procenjenu verovatnoću iz formule na prethodni interval, mi u stvari polazimo od verovatnoće 0,01 .

Imajući u vidu statistički način dobijanja verovatnoće i posmatrajući učestalost koja se nalazi u formuli kao korektivnu vrednost za procenjenu verovatnoću, možemo doći do zaključka da se stvarna verovatnoća (kao umnožak procenjene verovatnoće i relativne učestalosti) kreće u intervalu od 0,001 do 1. 
Dakle, pravilnik se bavi sa dosta velikim verovatnoćama pojavljivanja događaja koji mogu imati štetne posledice.

Sa druge strane, neznatni i prihvatljiv nivo rizika definiše se za vrednosti $0,1 \leq \mathrm{R} \leq 20$, a u ovu kategoriju ulaze $\mathrm{i}$ događaji:

(1) čije su posledice ozbiljne $\mathrm{P}=3$, procenjena verovatnoća $\mathrm{V}=1$ odigrava se u ograničenim slučajevima, sa dnevnom izloženošću $U=6$.

(2) čije su posledice ozbiljne $\mathrm{P}=3$, procenjena verovatnoća $\mathrm{V}=3$ (malo moguće), a učestalost $\mathrm{U}=2$ sa mesečnom izloženošću.

(3) čije su posledice veoma ozbiljne $\mathrm{P}=6$ (pojedinačne nesreće sa smrtnim ishodom), $\mathrm{V}=1$ odigrava se u ograničenim slučajevima, učestalost $\mathrm{U}=3$ na nedeljnom nivou.

(4) čije su posledice katastrofalne $P=10$ sa višestrukim smrtnim ishodom, mala verovatnoća $\mathrm{V}=1$ ali moguća u ograničenom broju slučajeva, sa učestalošću na mesečnom nivou $\mathrm{U}=2$.

U dopustiv nivo rizika $20<R \leq 70$ spadaju i događaji:

(1) čije su posledice ozbiljne $\mathrm{P}=3$, procenjena verovatnoća $\mathrm{V}=10$ (očekivano, skoro sigurno), sa mesečnom izloženošću $U=2$.

(2) čije su posledice veoma ozbiljne $\mathrm{P}=6$ (pojedinačne nesreće sa smrtnim ishodom), procenjena verovatnoća $\mathrm{V}=3$ (malo moguće), učestalost $\mathrm{U}=3$ na nedeljnom nivou.

(3) čije su posledice katastrofalne $\mathrm{P}=10$ sa višestrukim smrtnim ishodom, mala verovatnoća $\mathrm{V}=1$ ali moguća u ograničenom broju slučajeva, sa dnevnom izloženošću $U=6$.

A umeren nivo rizika $70<\mathrm{R} \leq 200$ obuhvata i događaje:

(1) čije su posledice ozbiljne $\mathrm{P}=3$, procenjena verovatnoća $\mathrm{V}=10$ (očekivano, skoro sigurno), sa dnevnom izloženošću $U=6$.

(2) čije su posledice veoma ozbiljne $\mathrm{P}=6$ (pojedinačne nesreće sa smrtnim ishodom), procenjena verovatnoća
$\mathrm{V}=10$ (očekivano, skoro sigurno), učestalost $\mathrm{U}=3$ na nedeljnom nivou.

(3) čije su posledice katastrofalne $P=10$ sa višestrukim smrtnim ishodom, sa verovatnoćom $\mathrm{V}=6$ (sasvim moguće) $\mathrm{i}$ učestalost $\mathrm{U}=3$ na nedeljnom nivou.

(4) čije su posledice katastrofalne $\mathrm{P}=10$ sa višestrukim smrtnim ishodom, mala verovatnoća $\mathrm{V}=1$, ali moguća u ograničenom broju slučajeva, učestalost $\mathrm{U}=10$ neprekidna.

Zaključujemo da ovako definisane vrednosti ovih parametara u pravilniku očigledno nisu dobro definisane i da ocene nivoa rizika dobijene na ovaj način uglavnom nisu primerene slučajevima neznatnog, prihvatljivog i umerenog rizika.

\section{REZIME}

$\mathrm{Na}$ osnovu napred rečenog, može se zaključiti da ovaj pravilnik u ovakvom obliku nije u realnosti potpuno primenljiv i da bi trebalo ozbiljnije pristupiti, pre svega procenama verovatnoća mogućih neželjenih događaja. Samim tim bi i procene nivoa rizika bile preciznije određene, i menadžeri u preduzećima bi mogli dobiti jasnije slike o načinima delovanja u cilju sprečavanja neželjenih događaja.

\section{LITERATURA}

GS PUT Nezavisnost. (2015). Svetski dan bezbednosti i zdravlja na radu. Preuzeto 31. oktobra 2015. sa http://www.gsputnezavisnost.org.rs/nuke/

Kinney, G.F., \& Wiruth, A.D. (1976). Practical risk analysis for safety management, NWC Technical publication 5865, Naval Weapons Center, China Lake CA, USA.

Starčević, J., Ilić, M., \& Paunović-Pfaf, J. (2010). Priručnik za procenu rizika. Beograd: Globe Design.

Unija poslodavaca Srbije. (2015). Smernice za procenu rizika. Preuzeto 31. oktobra 2015. sa http://www.poslodavci.org.rs/ aktivnosti/projekti/bezbednost-i-zdravlje-na-radu/procena-rizika

\section{THE ANALYSIS OF FORMULA FOR RISK LEVEL CALCULATION}

\section{Abstract:}

In this paper, the authors analyse the formula used for calculating risk level according to the Kinney method: the risk is viewed as a quantitative value obtained based on the probability of its occurrence, severity of its consequences (e.g. injuries, diseases, death) and the frequency of its occurrence and its adverse effects.

\section{Key words:}

risk level,

consequence,

probability,

frequency. 